\begin{tabular}{|c|l|}
\hline Title & $\begin{array}{l}\text { Removal of residual dissolved methane gas in an upflow anæerobic sludge blanket reactor treating low-strength } \\
\text { wastewater at low temperature with degassing membrane }\end{array}$ \\
\hline Author(s) & $\begin{array}{l}\text { Bandara, Wasala M. K. R. T. W.; Satoh, Hisashi; Sasakawa, Manabu; Nakahara, Y oshinito; Takahashi, Masahiro; } \\
\text { Okabe, Satoshi }\end{array}$ \\
\hline Citation & $\begin{array}{l}\text { Water Research, 45(11), 3533-3540 } \\
\text { https://doi.org/10.1016).watres.2011.04.030 }\end{array}$ \\
\hline Issue Date & 2011 \\
\hline Doc URL & http://hdl.handle.net/2115/45460 \\
\hline Type & article (author version) \\
\hline File Information & wasala_WR.pdf \\
\hline
\end{tabular}

Instructions for use 


\section{Removal of residual dissolved methane gas in an upflow anaerobic sludge blanket reactor treating low-strength wastewater at low temperature with degassing membrane}

Wasala M. K. R. T. W. Bandara ${ }^{\mathrm{a}}$, Hisashi Satoh ${ }^{\mathrm{a}, *}$, Manabu Sasakawa $^{\mathrm{b}}$, Yoshihito Nakahara $^{\mathrm{b}}$, Masahiro Takahashi ${ }^{\mathrm{a}}$, and Satoshi Okabe ${ }^{\mathrm{a}}$

a Division of Environmental Engineering, Faculty of Engineering, Hokkaido University, North-13, West-8, Sapporo 060-8628, Japan

b Mitsubishi Rayon Co., Ltd., 1-2, Ushikawa-dori 4-chome, Toyohashi-shi, Aichi 440-8601, Japan

*Corresponding author.

Mailing address:

Hisashi Satoh

Division of Environmental Engineering, Faculty of Engineering, Hokkaido University, North-13, West-8, Sapporo 060-8628, Japan.

Tel: $+81-(0) 11-706-6277$

Fax: +81-(0)11-706-6277

E-mail: qsatoh@eng.hokudai.ac.jp 


\begin{abstract}
In this study, we investigated the efficiency of dissolved methane $\left(\mathrm{D}-\mathrm{CH}_{4}\right)$ collection by degasification from the effluent of a bench-scale upflow anaerobic sludge blanket (UASB) reactor treating synthetic wastewater. A hollow-fiber degassing membrane module was used for degasification. This module was connected to the liquid outlet of the UASB reactor. After chemical oxygen demand (COD) removal efficiency of the UASB reactor became stable, $\mathrm{D}-\mathrm{CH}_{4}$ discharged from the UASB reactor was collected. Under $35^{\circ} \mathrm{C}$ and a hydraulic retention time (HRT) of $10 \mathrm{~h}$, average D-CH 4 concentration could be reduced from $63 \mathrm{mg} \mathrm{COD} \mathrm{L}^{-1}$ to $15 \mathrm{mg} \mathrm{COD}^{-}$ $\mathrm{L}^{-1}$; this, in turn, resulted in an increase in total methane $\left(\mathrm{CH}_{4}\right)$ recovery efficiency from $89 \%$ to $97 \%$. Furthermore, we investigated the effects of temperature and HRT of the UASB reactor on degasification efficiency. Average $\mathrm{D}-\mathrm{CH}_{4}$ concentration was as high as $104 \mathrm{mg} \mathrm{COD} \mathrm{L}^{-1}$ at $15^{\circ} \mathrm{C}$ because of the higher solubility of $\mathrm{CH}_{4}$ gas in liquid; the average D-CH 4 concentration was reduced to $14 \mathrm{mg} \mathrm{COD} \mathrm{L}{ }^{-1}$ by degasification. Accordingly, total $\mathrm{CH}_{4}$ recovery efficiency increased from $71 \%$ to $97 \%$ at $15^{\circ} \mathrm{C}$ as a result of degasification. Moreover, degasification tended to cause an increase in particulate COD removal efficiency. The UASB reactor was operated at the same COD loading rate, but different wastewater feed rates and HRTs. Although average D-CH concentration in the UASB reactor was almost unchanged (ca. $70 \mathrm{mg} \mathrm{COD} \mathrm{L}^{-1}$ ) regardless of the HRT value, the $\mathrm{CH}_{4}$ discharge rate from the UASB reactor increased because of an increase in the wastewater feed rate. Because the $\mathrm{D}-\mathrm{CH}_{4}$ concentration could be reduced down to $12 \pm 1 \mathrm{mg} \mathrm{COD} \mathrm{L}^{-1}$ by degasification at an HRT of $6.7 \mathrm{~h}$, the
\end{abstract}


$\mathrm{CH}_{4}$ recovery rate was 1.5 times higher under degasification than under normal operation.

Keywords: Dissolved methane gas; Degassing membrane; Anaerobic wastewater treatment; Low temperature; Low-strength wastewater 


\section{Introduction}

Anaerobic wastewater treatment is a well-established and proven technology for the treatment of various categories of industrial wastewaters (Cakir and Stenstrom, 2005). This technology has numerous advantages, such as low energy requirement and energy recovery as methane $\left(\mathrm{CH}_{4}\right)$ gas, over aerobic wastewater treatment systems. Most anaerobic wastewater treatments have been conducted within mesophilic $\left(30-40^{\circ} \mathrm{C}\right)$ or thermophilic $\left(45-60^{\circ} \mathrm{C}\right)$ temperature ranges (Kashyap et al., 2003; Dhaked et al., 2010; Fang et al., 2006; Lettinga et al., 2001). This is attributed to the fact that most of the biological reactions responsible for anaerobic biodegradation of organic matter proceeds much slower under psychrophilic $\left(<20^{\circ} \mathrm{C}\right)$ conditions than under mesophilic conditions. However, domestic wastewater and a variety of industrial wastewaters, such as those from bottling, malting, and soft drinks manufacturing plants and breweries, are generally discharged at low ambient temperatures under temperate climatic conditions. Furthermore, domestic sewage wastewaters belong to the category of "low-strength wastewaters" that have a chemical oxygen demand (COD) concentration of ca. $1.0 \mathrm{~g} \mathrm{~L}^{-1}$ or lower. Therefore, a significant input of energy is required to heat the reactor to the treatment temperature (Lettinga et al., 2001; Angenent et al., 2001). If anaerobic wastewater treatment without heating the reactors can be applied to low-strength wastewater, the cost of anaerobic wastewater treatment can be reduced, thereby making this technology an attractive option for the treatment of a variety of wastewater categories. 
Improvements in reactor design and operational conditions have helped overcome many of the disadvantages of anaerobic wastewater treatment that limited its application to high-strength wastewater treatment at mesophilic or thermophilic temperatures and have allowed for successful operation of anaerobic wastewater treatment reactors at low temperatures (Dhaked et al., 2010; Lettinga et al., 1999; Lettinga et al., 2001; Trzcinski and Stuckey 2010; Luostarinen and Rintala 2005; Madden et al., 2010; Xing et al., 2009; McKeown et al., 2009). In addition, several studies have focused on anaerobic wastewater treatment of low-strength wastewaters at lower temperatures (Elmitwalli et al., 2003; Angenent et al., 2001; Gomec et al., 2008; Matsushige et al., 1990). A drop in temperature causes a change in the physical and chemical properties of wastewater, and this can significantly affect the reactor performance. For instance, dissolved methane gas $\left(\mathrm{D}-\mathrm{CH}_{4}\right)$ might play an important role in energy recovery efficiency of the reactor; however, to date, the role of $\mathrm{D}-\mathrm{CH}_{4}$ has been overlooked. Discharge of residual D-CH 4 in the reactor effluent represents a loss of energy that may be recovered; in addition, $\mathrm{D}-\mathrm{CH}_{4}$ is a source of $\mathrm{CH}_{4}$, a greenhouse gas, that may be released into the environment (Hartley and Lant, 2006; Hatamoto et al., 2010; Matsuura et al., 2010). This knowledge is particularly important when low-strength wastewaters are anaerobically treated at low temperature, because the solubility of $\mathrm{CH}_{4}$ in the liquid phase increases with a decrease in temperature. Few studies have investigated the removal of $\mathrm{D}-\mathrm{CH}_{4}$ in anaerobic wastewater treatment processes by biological oxidation, physical gasification based on gas-liquid equilibrium, and mixing with gas or a paddle (Hartley and Lant, 2006; 
Hatamoto et al., 2010; Matsuura et al., 2010; Pauss et al., 1990). However, the recovery efficiency of D-CH $\mathrm{CH}_{4}$ was low and/or the recovered $\mathrm{CH}_{4}$ gas composition was low in these processes. Hence, another technology is required for the removal of D-CH 4 (Voolapalli and Stuckey, 1998).

In this study, we employed a hollow-fiber membrane to recover residual $\mathrm{D}-\mathrm{CH}_{4}$ in the effluent of an anaerobic wastewater treatment reactor by degasification. A bench-scale upflow anaerobic sludge blanket (UASB) reactor was operated, and the liquid outlet of the UASB reactor was connected to another reactor for degasification. After achieving stable COD removal efficiency, the $\mathrm{D}-\mathrm{CH}_{4}$ discharged from the UASB reactor was recovered by the degassing membrane (DM) reactor. In addition, we investigated the effects of temperature and hydraulic retention time (HRT) of the UASB reactor on the efficiency of degasification.

\section{Materials and methods}

2.1. Experimental setup and operational conditions

A bench-scale UASB reactor (height, $40 \mathrm{~cm}$; diameter, $7 \mathrm{~cm}$; working volume, 1.3 L) was operated in this study. The reactor was inoculated with $0.3 \mathrm{~L}$ of anaerobic granular sludge, which had total and volatile solids concentrations of $28 \mathrm{~g} \mathrm{~L}^{-1}$ and $22 \mathrm{~g}$ $\mathrm{L}^{-1}$, respectively, obtained from a full-scale UASB reactor treating wastewater from an isomerized sugar-processing plant. The UASB reactor was covered with a water jacket 
to maintain the reactor at a constant temperature $\left(15,25\right.$, or $\left.35^{\circ} \mathrm{C}\right)$. The reactor was fed with synthetic wastewater containing powdered skim milk as carbon and energy sources, inorganic salts, and trace metals (Satoh et al., 2007). COD concentration was controlled by changing the concentration of powdered milk. HRT was adjusted by altering the wastewater feed rate. These operational conditions are summarized in Table 1. $\mathrm{pH}$ of the bulk liquid in the UASB reactor was maintained by adding $\mathrm{NaOH}$ at 7.6 after 51 days.

After gas production reached a steady state, dissolved gas in the liquid was collected by the DM. A reactor for degasification (height, $30 \mathrm{~cm}$; diameter, $7 \mathrm{~cm}$; working volume, 1.1 L) was connected to the liquid outlet of the UASB reactor to collect the residual $\mathrm{D}-\mathrm{CH}_{4}$ in the UASB effluent by degasification. A hollow-fiber membrane module (a multi-layered composite hollow-fiber membrane; MHF0504MBFT) provided by the Mitsubishi Rayon Co., Ltd. (Tokyo, Japan) was installed in the DM reactor. The DM reactor was completely filled with the wastewater treated in the UASB reactor. The liquid in the DM reactor was not mixed. The characteristics of the DM module are summarized in Table 2. The dissolved biogas diffuses into the lumen of the hollow fibers of the DM under vacuum generated using a vacuum pump (Model APN-110KV-1; Iwaki Co., Ltd., Tokyo, Japan). Although gas molecules can pass through the non-porous layer of the membrane, liquids cannot. Thus, the DM effectively separates dissolved gas from the liquid. The DM reactor was operated at same temperatures as the UASB reactor. Transmembrane pressures were set at $50 \mathrm{kPa}$ and $80 \mathrm{kPa}$ (absolute pressure) by using a vacuum gauge, and HRTs of the 
DM reactor were altered in accordance with variations in the HRTs of the UASB reactor (Table 1). The operation of the DM reactor without degasification is referred to as normal operation.

2.2. Analytical methods

The concentrations of total COD (T-COD) and dissolved fraction of COD (D-COD) after filtration with a 0.45 - $\mu$ m-pore-size membrane (Advantec Co., Ltd., Tokyo, Japan) were measured using a Hach method (Method 8000). Particulate COD (P-COD) concentration was calculated by subtracting the D-COD concentration from the T-COD concentration. The concentrations of volatile fatty acids (VFAs; formate, acetate, propionate, lactate, i-butyrate, and n-butyrate) were determined by using a high-performance liquid chromatography system (LC-10AD system; Shimadzu Co., Kyoto, Japan) equipped with a Shimadzu Shim-pack SCR-102H column $(0.8 \times 30 \mathrm{~cm})$ after filtering it through a $0.2-\mu \mathrm{m}$-pore-size membrane. The oxidation-reduction potential (ORP) and $\mathrm{pH}$ were directly determined by using an ORP and a $\mathrm{pH}$ electrode, respectively.

Concentrations of $\mathrm{CH}_{4}, \mathrm{CO}_{2}, \mathrm{~N}_{2}, \mathrm{O}_{2}$, and $\mathrm{H}_{2}$ in the headspace of the UASB reactor and inside the lumen of the hollow fibers of the DM were measured by using a gas chromatography system (GC-14B; Shimadzu Co., Kyoto, Japan) equipped with a thermal-conductivity detector and a Shincarbon-ST column (Shimadzu Co., Kyoto, Japan). The biogas volumes were measured at $25^{\circ} \mathrm{C}$. The dissolved gas compositions 
were measured by using the headspace method (Bandara et al., submitted). Liquid samples $(50 \mathrm{~mL})$ were obtained from the UASB and DM reactors and were injected with a syringe into a sealed vial $(125 \mathrm{~mL})$ that was prefilled with $100 \%$ argon gas. We then added $1 \mathrm{~mL}$ of $20 \mathrm{mM}$ mercury (II) chloride to the vial to inhibit biological reactions. The vial was vigorously shaken for $5 \mathrm{~min}$ to allow for diffusion of the dissolved gas in the liquid sample into the headspace. The liquid sample was allowed to stand for $30 \mathrm{~min}$ at room temperature to equilibrate the gas and liquid phases. Then, the composition of the headspace gas was determined using gas chromatography. The standard liquid sample with known concentration of each standard gas was prepared as follows. A vial (125 mL) was filled with $50 \mathrm{~mL}$ of distilled water. Argon gas was blown into the distilled water in the vial for $5 \mathrm{~min}$ to remove air in the liquid and gas phases. The vial was then sealed with a butyl rubber septum. Next, we injected $1 \mathrm{~mL}$ of $100 \%$ of each gas, corresponding to $820 \mu \mathrm{mol}$ at $25^{\circ} \mathrm{C}$, to the vial. The vial was shaken and allowed to stand for $30 \mathrm{~min}$, and then, the composition of the headspace gas was determined by gas chromatography. The concentrations of dissolved gases in the sample liquid were calculated on the basis of the ratio of the amount of gas in the sample to that in the standard sample. All measurements were conducted at a constant temperature of $25^{\circ} \mathrm{C}$.

On the basis of these results, $\mathrm{D}-\mathrm{CH}_{4}$ collection efficiency was calculated as a ratio of $\mathrm{D}-\mathrm{CH}_{4}$ concentration collected by the $\mathrm{DM}$ to $\mathrm{D}-\mathrm{CH}_{4}$ discharged from the UASB reactor. The D-CH 4 concentration in the DM was calculated as the difference between the D-CH 4 concentrations discharged from the UASB and DM reactors. Total 
$\mathrm{CH}_{4}$ recovery efficiency was calculated as a ratio of the $\mathrm{CH}_{4}$ recovery rate (mg COD $\mathrm{L}^{-1}$ day $\left.^{-1}\right)$ to the total $\mathrm{CH}_{4}$ production rate $\left(\mathrm{mg} \mathrm{COD} \mathrm{L}{ }^{-1}\right.$ day $\left.{ }^{-1}\right)$. The $\mathrm{CH}_{4}$ recovery rate is defined as the sum of the $\mathrm{CH}_{4}$ evolution rate in the UASB headspace and $\mathrm{CH}_{4}$ collection rate in the DM. The total $\mathrm{CH}_{4}$ production rate is defined as the sum of the $\mathrm{CH}_{4}$ evolution rate, $\mathrm{CH}_{4}$ collection rate, and $\mathrm{CH}_{4}$ discharge rate from the DM reactor.

\section{Results and discussion}

\subsection{Performance of the UASB reactor}

The bench-scale UASB reactor was operated at different temperatures and HRTs for 170 days, and concentrations of influent T-COD and effluent T-COD and D-COD in the UASB reactor were measured (Figure 1). The average T-COD concentration ( \pm standard deviation) of the influent was $1480 \pm 240 \mathrm{mg} \mathrm{COD} \mathrm{L}^{-1}$ from startup to day 128 (by phase 4), after which the influent T-COD concentrations decreased. Even at the beginning of reactor operation, D-COD removal efficiency was high (Figure 1), probably because of the high amount of biomass, although the influent and effluent T-COD concentrations fluctuated. The average effluent D-COD concentration was 120 $\pm 40 \mathrm{mg} \mathrm{COD} \mathrm{L}^{-1}$ by day 128 , resulting in a D-COD removal efficiency as high as $92 \pm$ $2 \%$. Total VFA concentration in the UASB reactor was less than $68 \mathrm{mg} \mathrm{COD} \mathrm{L}^{-1}$ for 170 days (data not shown). The dominant VFA was acetate, with a maximal

concentration of $53 \mathrm{mg} \mathrm{COD} \mathrm{L}{ }^{-1}$ and average concentration of $28 \pm 14 \mathrm{mg} \mathrm{COD} \mathrm{L}^{-1}$ for 
170 days. The second dominant VFA was propionate $\left(9 \pm 6 \mathrm{mg} \mathrm{COD} \mathrm{L}^{-1}\right)$; the concentrations of other VFAs (lactate, formate, i-butyrate, and n-butyrate) were less than $1 \mathrm{mg} \mathrm{COD} \mathrm{L}^{-1}$.

\subsection{Performance of the DM reactor}

Since the reactor performance (e.g., the D-COD removal efficiency of the UASB reactor) became stable after adjusting the $\mathrm{pH}$ to 7.6 after day 51, degasification was conducted at a transmembrane pressure (absolute pressure) of $50 \mathrm{kPa}$ from day 64 (phase 1.2) to recover residual dissolved $\mathrm{CH}_{4}\left(\mathrm{D}-\mathrm{CH}_{4}\right)$ in the UASB effluent. The average D- $\mathrm{CH}_{4}$ concentration was $61 \pm 6 \mathrm{mg} \mathrm{COD} \mathrm{L}^{-1}$ during normal operation (phase 1.1); in contrast, it was $20 \pm 4 \mathrm{mg} \mathrm{COD} \mathrm{L}^{-1}$ in the effluent of the DM reactor during a degasification period (Phase 1.2) (Figure 2). The difference between the $\mathrm{D}-\mathrm{CH}_{4}$ concentrations in the effluents of the UASB and DM reactors indicated that $\mathrm{D}-\mathrm{CH}_{4}$ was successfully collected by the DM during a degasification period. The transmembrane pressure was further reduced by $20 \mathrm{kPa}$ (absolute pressure) at day 78 (phase 1.3) to reduce the residual $\mathrm{D}-\mathrm{CH}_{4}$ in the UASB effluent. The $\mathrm{D}-\mathrm{CH}_{4}$ concentration was $15 \pm 5$ $\operatorname{mg~COD~L}{ }^{-1}$ in the DM reactor effluent in phase 1.3 (Figure 2). On the basis of these results, $\mathrm{D}-\mathrm{CH}_{4}$ collection efficiencies were calculated to be $68 \pm 7 \%$ and $77 \pm 7 \%$ in phases 1.2 and 1.3, respectively. When the DM reactor was applied to pure water at 0.3 $\mathrm{kPa}$, dissolved oxygen concentration was decreased to less than $0.1 \mathrm{mg} \mathrm{L}^{-1}$ after $5 \mathrm{~min}$, indicating that the theoretical dissolved gas collection efficiency of the DM was almost 
$100 \%$. To check for reproducibility of the efficiency of degasification, vacuum was discontinued at day 85 (phase 1.4). The average $\mathrm{D}-\mathrm{CH}_{4}$ concentration was $63 \pm 1 \mathrm{mg}$ $\mathrm{COD} \mathrm{L}^{-1}$ in the $\mathrm{DM}$ reactor effluent in phase 1.4 , and this concentration was comparable to that before degasification (phase 1.1) (Figure 2). These results clearly indicated that D-CH 4 was successfully collected by degasification with the DM.

Discharge of residual D-CH 4 in the effluent of wastewater treatment reactors contributes to an increase in atmospheric $\mathrm{CH}_{4}$, which is 21 times more potent than $\mathrm{CO}_{2}$ as a greenhouse gas (Hartley and Lant, 2006). In addition, the $\mathrm{D}-\mathrm{CH}_{4}$ discharge represents a loss of energy that is generated in anaerobic wastewater treatment processes. Therefore, recovery of $\mathrm{D}-\mathrm{CH}_{4}$ from the effluent of the anaerobic wastewater treatment reactors is a prerequisite for the discharge of the effluent into the environment.

Gas compositions in the headspace of the UASB reactor (Figure 3A) and inside the lumen of the hollow fibers of the DM (Figure 3B) are shown in Figure 3. Although gas compositions fluctuated until day 50 , they became relatively stable thereafter because of $\mathrm{pH}$ adjustment to 7.6. Average $\mathrm{CH}_{4}$ compositions in the UASB headspace during the degasification period (phases 1.2 and 1.3 ) were $51 \pm 4 \%$ and $58 \pm 5 \%$, respectively, and they were $49 \pm 12 \%$ and $56 \pm 3 \%$ during normal operation (phases 1.1 and 1.4, respectively) (Figure 3A). Thus, degasification did not significantly affect the $\mathrm{CH}_{4}$ composition in the UASB headspace. Average compositions of $\mathrm{CH}_{4}$ and $\mathrm{CO}_{2}$ collected through the DM during the degasification period were $22 \pm 13 \%$ and $10 \pm 7 \%$, respectively, in phase 1.2 and $20 \pm 2 \%$ and $27 \pm 6 \%$, respectively, in phase 1.3 (Figure 
3B).

$\mathrm{O}_{2}$ was detected in the biogas collected through the DM; this indicated the ingress of air into the dissolved gas collection line. The percentage of $\mathrm{N}_{2}$ plus $\mathrm{O}_{2}$ in the collected biogas varied from $39 \%$ to $87 \%$ in phase 1 . The ratios of $\mathrm{N}_{2}$ to $\mathrm{O}_{2}$ were 3.9 or higher, and these ratios were greater than the ratio of $\mathrm{N}_{2}$ to $\mathrm{O}_{2}$ in air (79/21 or 3.76). This was because the dissolved biogas itself contained $\mathrm{N}_{2}$ but not $\mathrm{O}_{2}$. If air had been excluded from the collected biogas, the average $\mathrm{CH}_{4}$ composition in the collected gas would have been $63 \pm 15 \%$ in phase 1.2 , which would have been comparable to that in the UASB headspace.

Several approaches for removal and/or recovery of $\mathrm{D}-\mathrm{CH}_{4}$ in wastewater treatment processes have been investigated. Hatamoto et al. (2010) used an encapsulated down-flow hanging sponge (DHS) reactor to biologically oxidize the D- $\mathrm{CH}_{4}$; although this technique enabled oxidization of $95 \%$ of the $\mathrm{D}-\mathrm{CH}_{4}$, no D-CH 4 was recovered as $\mathrm{CH}_{4}$ gas. In contrast, Matsuura et al. (2010) employed a two-stage DHS reactor for post-treatment of the effluent from a UASB reactor treating municipal sewage to recover and oxidize D-CH . The first-stage reactor could recover $\mathrm{D}-\mathrm{CH}_{4}$ with $77 \%$ recovery efficiency. However, $\mathrm{CH}_{4}$ compositions in the recovered biogas were relatively low because of an inherent limitation of this method-the $\mathrm{D}-\mathrm{CH}_{4}$ is released from a liquid in the DHS reactor by physical gasification based on the gas-liquid equilibrium. Another approach for removing $\mathrm{D}-\mathrm{CH}_{4}$ involved mixing the liquid in an anaerobic wastewater treatment reactor with gas or a paddle. Hartley and Lant (2006) applied intermittent gas mixing by micro-aeration with biogas-containing 
air, and this resulted in the release of $\mathrm{D}-\mathrm{CH}_{4}$ into the gas phase of the reactor. However, the $\mathrm{CH}_{4}$ composition in the recovered biogas was lower than that in the reactor headspace in the absence of aeration, because the gas used for aeration diluted the biogas. Recovered biogas with low $\mathrm{CH}_{4}$ concentration is unsuitable for subsequent energy generation processes. Pauss et al. (1990) mixed the liquid phase in reactors with a paddle or by recirculating the supernatant liquid to enhance the evolution of D-CH 4 and gas bubbles attached to solid particles from the liquid phase to gas phase. However, in this method, the D- $\mathrm{CH}_{4}$ concentration would theoretically never be lower than the saturation concentration of $\mathrm{D}-\mathrm{CH}_{4}$. Another possible process is to apply vacuum directly to the reactor. It does not seem to be realistic, because the reactor must be closed completely and a pressure tight case.

In order to check the mass balance of $\mathrm{CH}_{4}$, the $\mathrm{CH}_{4}$ evolution rate in the UASB headspace, $\mathrm{CH}_{4}$ collection rate from the $\mathrm{DM}$, and $\mathrm{CH}_{4}$ discharge rate from the DM reactor were calculated using the $\mathrm{CH}_{4}$ concentrations and flow rates of wastewater and biogas described above. Figure 4 shows the rates of $\mathrm{CH}_{4}$ discharged from the UASB reactor and total $\mathrm{CH}_{4}$ recovery efficiency in addition to the 3 above-mentioned $\mathrm{CH}_{4}$ production rates and their averaged values were summarized in Table 1 . The average $\mathrm{CH}_{4}$ evolution rates were $1000 \pm 94 \mathrm{mg} \mathrm{COD} \mathrm{L}^{-1}$ day $^{-1}$ and $1120 \pm 110 \mathrm{mg} \mathrm{COD} \mathrm{L}^{-1}$ day $^{-1}$ during the degasification period (phases 1.2 and 1.3, respectively). These rates were comparable to those during normal operation $\left(960 \pm 220 \mathrm{mg} \mathrm{COD} \mathrm{L}^{-1}\right.$ day $^{-1}$ in phase 1.1 and $1010 \pm 230 \mathrm{mg} \mathrm{COD} \mathrm{L}^{-1} \mathrm{day}^{-1}$ in phase 1.4). Thus, degasification did not significantly affect the $\mathrm{CH}_{4}$ evolution rate in the UASB reactor. In contrast, the average 
$\mathrm{CH}_{4}$ discharge rates were lower during the degasification period $\left(49 \pm 10 \mathrm{mg} \mathrm{COD} \mathrm{L}^{-1}\right.$ day $^{-1}$ in phase 1.2 and $35 \pm 11 \mathrm{mg} \mathrm{COD} \mathrm{L}$ day $^{-1}$ in phase 1.3 ) than during normal operation $\left(140 \pm 14 \mathrm{mg} \mathrm{COD} \mathrm{L}{ }^{-1}\right.$ day $^{-1}$ in phase 1.1 and $150 \pm 3 \mathrm{mg} \mathrm{COD} \mathrm{L}^{-1}$ day $^{-1}$ in phase 1.4) because of the collection of $\mathrm{D}-\mathrm{CH}_{4}$ with the DM. The $\mathrm{D}-\mathrm{CH}_{4}$ discharge rate accounted for $11 \pm 3 \%$ of the total $\mathrm{CH}_{4}$ production rate during the normal operation (Phase 1.1), whereas it was $2.6 \pm 0.8 \%$ during the degasification period (phase 1.3). The average $\mathrm{CH}_{4}$ collection rates were $180 \pm 85 \mathrm{mg} \mathrm{COD} \mathrm{L}^{-1}$ day $^{-1}$ in phase 1.2 and $210 \pm 26 \mathrm{mg} \mathrm{COD} \mathrm{L}^{-1} \mathrm{day}^{-1}$ in phase 1.3 (Figure 4). On the basis of these results, the total $\mathrm{CH}_{4}$ production rates were calculated to be $1090 \pm 230 \mathrm{mg} \mathrm{COD} \mathrm{L}^{-1}$ day $^{-1}$ in phase 1.1 and $1160 \pm 230 \mathrm{mg} \mathrm{COD} \mathrm{L}{ }^{-1}$ day $^{-1}$ in phase 1.4. In contrast, these rates were slightly higher $\left(1220 \pm 140 \mathrm{mg} \mathrm{COD} \mathrm{L}{ }^{-1}\right.$ day $^{-1}$ in phase 1.2 and $1370 \pm 130 \mathrm{mg}$ COD $\mathrm{L}^{-1}$ day $^{-1}$ in phase 1.3) during the degasification period, probably because of $\mathrm{CH}_{4}$ production in the DM reactor. Accordingly, $\mathrm{D}-\mathrm{CH}_{4}$ collection efficiencies were $68 \pm$ $7 \%$ and $77 \pm 7 \%$ in phases 1.2 and 1.3 , respectively, and total $\mathrm{CH}_{4}$ recovery efficiencies increased up to $96 \pm 1 \%$ and $97 \pm 1 \%$ during the degasification period (phases 1.2 and 1.3, respectively), as compared to those during normal operation ( $89 \pm$ $3 \%$ in phase 1.1 and $90 \pm 2 \%$ in phase 1.4$)$.

\subsection{Effect of temperature}

The UASB and DM reactors were operated at low temperatures $\left(25^{\circ} \mathrm{C}\right.$ and $15^{\circ} \mathrm{C}$ in phases 2 and 3, respectively). The average $\mathrm{D}-\mathrm{CH}_{4}$ concentrations in the UASB 
reactor were $63 \pm 4 \mathrm{mg} \mathrm{COD} \mathrm{L}^{-1}$ at $35^{\circ} \mathrm{C}$ throughout phase $1,82 \pm 7 \mathrm{mg} \mathrm{COD} \mathrm{L}^{-1}$ at $25^{\circ} \mathrm{C}$ throughout phase 2 , and $104 \pm 5 \mathrm{mg} \mathrm{COD} \mathrm{L}^{-1}$ at $15^{\circ} \mathrm{C}$ throughout phase 3 (Figure 2). The increase in $\mathrm{D}-\mathrm{CH}_{4}$ concentrations at lower temperatures was attributed to an increase in the solubility of $\mathrm{CH}_{4}$ in the liquid phase with decreasing temperature. Corresponding with the increase in $\mathrm{D}-\mathrm{CH}_{4}$ concentration, average $\mathrm{D}-\mathrm{CH}_{4}$ discharge rates increased from $150 \pm 12 \mathrm{mg} \mathrm{COD} \mathrm{L}^{-1} \mathrm{day}^{-1}$ at $35^{\circ} \mathrm{C}$ to $200 \pm 20 \mathrm{mg} \mathrm{COD} \mathrm{L}^{-1}$ day $^{-1}$ at $25^{\circ} \mathrm{C}$ and $250 \pm 13 \mathrm{mg} \mathrm{COD} \mathrm{L}^{-1}$ day $^{-1}$ at $15^{\circ} \mathrm{C}$, thereby indicating that the loss of $\mathrm{D}-\mathrm{CH}_{4}$ from the UASB reactor was more significant at lower temperatures.

Degasification enabled successful collection of $\mathrm{D}-\mathrm{CH}_{4}$ by the $\mathrm{DM}$ regardless of temperature. The D-CH 4 concentrations decreased to $13 \pm 4 \mathrm{mg} \mathrm{COD} \mathrm{L}^{-1}$ at $25^{\circ} \mathrm{C}$ (phase 2.2) and $14 \pm 2 \mathrm{mg} \mathrm{COD} \mathrm{L}^{-1}$ at $15^{\circ} \mathrm{C}$ (phase 3.2) in the DM reactor. The ratio of D- $\mathrm{CH}_{4}$ concentration to $\mathrm{CH}_{4}$ composition in the UASB headspace increased with decreasing temperature. Therefore, the $\mathrm{CH}_{4}$ collection rates showed a relative increase from $210 \pm 26 \mathrm{mg} \mathrm{COD} \mathrm{L}^{-1} \mathrm{day}^{-1}$ at $35^{\circ} \mathrm{C}$ (phase 1.3 ) to $300 \pm 84 \mathrm{mg} \mathrm{COD} \mathrm{L}^{-1} \mathrm{day}^{-1}$ at $25^{\circ} \mathrm{C}$ (phase 2.2) and to $370 \pm 100 \mathrm{mg} \mathrm{COD} \mathrm{L}^{-1}$ day $^{-1}$ at $15^{\circ} \mathrm{C}$ (phase 3.2 ). Accordingly, total $\mathrm{CH}_{4}$ recovery efficiency increased from $71 \%$ in phase 3.1 to $97 \%$ at $15^{\circ} \mathrm{C}$ by degasification (phase 3.2), and $\mathrm{D}-\mathrm{CH}_{4}$ collection efficiencies increased with a decrease in temperature from $77 \pm 7 \%$ at $35^{\circ} \mathrm{C}$ to $85 \pm 4 \%$ at $25^{\circ} \mathrm{C}$ and $86 \pm 2 \%$ at $15^{\circ} \mathrm{C}$.

$\mathrm{CH}_{4}$ evolution rates in the UASB headspace decreased with a decrease in temperature (Figure 4); $1000 \pm 170 \mathrm{mg} \mathrm{COD} \mathrm{L}^{-1}$ day $^{-1}$ throughout phase $1,860 \pm 140$ $\operatorname{mg~COD~L}{ }^{-1}$ day $^{-1}$ throughout phase 2 , and $650 \pm 100 \mathrm{mg} \mathrm{COD} \mathrm{L}^{-1}$ day $^{-1}$ throughout phase 3. D-COD removal efficiency was not considerably decreased at lower 
temperatures $(94 \%, 89 \%$ and $91 \%$ in Phases $1.3,2.2$ and 3.2, respectively). This finding indicated that microbial $\mathrm{CH}_{4}$ production activity was maintained even at low temperatures probably because of the presence of sufficient amount of biomass and high bioavailability of influent organic materials. Hence, the decrease in the $\mathrm{CH}_{4}$ evolution rate might be due to an increase in the solubility of $\mathrm{CH}_{4}$ in the liquid phase (Lettinga et al., 2001).

The $\mathrm{CH}_{4}$ recovery rates at $25^{\circ} \mathrm{C}\left(1230 \pm 54 \mathrm{mg} \mathrm{COD} \mathrm{L}^{-1}\right.$ day $^{-1}$ in phase 2.2$)$ and at $15^{\circ} \mathrm{C}\left(1060 \pm 150 \mathrm{mg} \mathrm{COD} \mathrm{L}^{-1} \mathrm{day}^{-1}\right.$ in phase 3.2) were higher than the $\mathrm{CH}_{4}$ evolution rate at $35^{\circ} \mathrm{C}$ during normal operation $\left(1000 \pm 170 \mathrm{mg} \mathrm{COD} \mathrm{L}^{-1}\right.$ day $^{-1}$ throughout phase 1). Thus, it can be concluded that the degasification technology enables us to recover $\mathrm{CH}_{4}$ in a UASB process at low temperature without heating, and the amount of $\mathrm{CH}_{4}$ produced in the UASB process is comparable to that produced in a conventional process under mesophilic conditions. In general, many types of wastewaters are discharged at low ambient temperatures under temperate climatic conditions. To treat such wastewaters under mesophilic condition, their temperature must be increased to the optimal mesophilic range. This requires a significant amount of energy, and the high energy cost is a heavy economic burden on such wastewater treatment systems (Lettinga et al., 2001). A UASB process that does not require heating is economically attractive (Dhaked et al., 2010; Angenent et al., 2001). However, the degasification technology also consumed much energy in this study (42 $\mathrm{J} \mathrm{s}^{-1}$ ). The maximal $\mathrm{CH}_{4}$ collection rate of $660 \mathrm{mg} \mathrm{COD} \mathrm{L}^{-1}$ day $^{-1}$ (Fig. 4) was comparable only to $0.14 \mathrm{~J} \mathrm{~s}^{-1}$, assuming that $1 \mathrm{~L}^{\text {of }} \mathrm{CH}_{4}$ has the energy of $35800 \mathrm{~J}$. 
Future studies must aim to reduce the energy required for degasification so that the degasification technology may be applied in real wastewater treatment processes.

Although the D-COD removal efficiency was slightly decreased at lower temperatures (phases 2 and 3), it was still higher than 87\%, and the effluent D-COD concentration was less than $200 \mathrm{mg} \mathrm{COD} \mathrm{L}^{-1}$ (Figure 1). In contrast, the P-COD concentration in the DM reactor, which was calculated as the difference between the effluent T-COD and D-COD concentrations, increased at lower temperatures, indicating a decrease in P-COD removal efficiency. At lower temperatures, particles might settle more slowly because of lower liquid-solid separation efficiency, which in turn may be attributed to higher liquid viscosity and/or attachment of gas bubbles onto the particles. Interestingly, the P-COD removal efficiency in the DM reactor was improved by degasification in phase 3 . This finding may be explained by the fact that a decrease in the dissolved gas concentration in the liquid in the DM reactor caused by degasification, followed by redissolution of the gas bubbles attached to the particles, caused the particles to efficiently settle down. The degasification technology might improve the efficiency of particle separation in a clarifier for a UASB reactor.

To verify the reproducibility of temperature effects, the temperature in the UASB reactor was set at $35^{\circ} \mathrm{C}$ again at day 123 . The average D-COD removal efficiency $(92 \pm$ $1 \%)$ and the $\mathrm{D}-\mathrm{CH}_{4}$ concentration $\left(66 \pm 5 \mathrm{mg} \mathrm{COD} \mathrm{L}^{-1}\right)$ in phase 4 were comparable to those in phase $1\left(94 \pm 2 \%\right.$ and $63 \pm 4 \mathrm{mg} \mathrm{COD} \mathrm{L}^{-1}$, respectively). This finding indicated that changes in chemical parameters (e.g., the D-CH4 $\mathrm{CH}_{4}$ concentration and the $\mathrm{CH}_{4}$ evolution rate in the UASB reactor) in phases 2 and 3 were attributed to lower 
temperatures.

\subsection{Effect of HRT}

The UASB reactor was again operated at $35^{\circ} \mathrm{C}$ but at lower COD concentrations (the concentrations throughout phase 5 and phase 6 were two-third and one-third, respectively, of that in phase 4) (Figure 1 and Table 1). In order to keep the COD loading rate of the UASB reactor constant, HRTs in phase $5(6.7 \mathrm{~h})$ and phase $6(3.3 \mathrm{~h})$ were also reduced to two-third and one-third, respectively, of the HRT in phase 4 (10 h) by increasing the wastewater feed rate. The average $\mathrm{D}-\mathrm{CH}_{4}$ concentration in the UASB reactor was ca. $70 \mathrm{mg} \mathrm{COD} \mathrm{L}{ }^{-1}$ in phases 4 to 7 because of the identical solubility of $\mathrm{CH}_{4}$ at a constant temperature $\left(35^{\circ} \mathrm{C}\right)$. The average $\mathrm{D}-\mathrm{CH}_{4}$ concentration was ca. $90 \%$ of the theoretical saturation concentration of D- $\mathrm{CH}_{4}$ at $35^{\circ} \mathrm{C}$ (Hartley and Lant, 2006). However, an increase in the wastewater feed rate resulted in an increase in the $\mathrm{CH}_{4}$ discharge rate from the UASB reactor (Figure 4). The $\mathrm{D}-\mathrm{CH}_{4}$ discharge rates were 160 $\pm 12 \mathrm{mg} \mathrm{COD} \mathrm{L}^{-1}$ day $^{-1}$ in phase $4,240 \pm 15 \mathrm{mg} \mathrm{COD} \mathrm{L}^{-1}$ day $^{-1}$ throughout phase 5 , and $500 \pm 35 \mathrm{mg} \mathrm{COD} \mathrm{L}^{-1}$ day $^{-1}$ throughout phase 6 . Degasification could reduce the D- $\mathrm{CH}_{4}$ concentration to $12 \pm 1 \mathrm{mg} \mathrm{COD} \mathrm{L}^{-1}$ in the DM reactor at an HRT of $6.7 \mathrm{~h}$ (phase 5.2). The average $\mathrm{CH}_{4}$ collection rate was $480 \pm 130 \mathrm{mg} \mathrm{COD} \mathrm{L}^{-1}$ day $^{-1}$ in phase 5.2, and this was much higher than that in phase $1.3\left(210 \pm 26 \mathrm{mg} \mathrm{COD} \mathrm{L}^{-1}\right.$ day $^{-1}$ ) because of the higher D-CH 4 concentration. The corresponding total $\mathrm{CH}_{4}$ recovery efficiency was $98 \%$ and the $\mathrm{CH}_{4}$ recovery rate was $1830 \pm 160 \mathrm{mg} \mathrm{COD} \mathrm{L}^{-1}$ 
day $^{-1}$, which was 1.5 times higher than that in normal operation at the same HRT in phase $5.1\left(1220 \pm 100 \mathrm{mg} \mathrm{COD} \mathrm{L}^{-1}\right.$ day $\left.^{-1}\right)$. These results indicate that the UASB process with degasification is a promising technology for effective $\mathrm{CH}_{4}$ recovery in low-strength wastewater treatment. Because of the economical benefits offered by the UASB process, its application to low-strength wastewater treatment has recently attracted much attention (Elmitwalli et al., 2003; Angenent et al., 2001; Gomec et al., 2008; Matsushige et al., 1990). At an HRT of 3.3 h, D-CH 4 remained at a high concentration $\left(51 \pm 3 \mathrm{mg} \mathrm{COD} \mathrm{L}^{-1}\right)$, and hence, the total $\mathrm{CH}_{4}$ recovery efficiency was as low as $76 \pm 2 \%$ during the degasification period (phase 6.2). This was probably because of insufficient HRT to collect D- $\mathrm{CH}_{4}$; however, the average $\mathrm{CH}_{4}$ collection rate was still high $\left(370 \pm 10 \mathrm{mg} \mathrm{COD} \mathrm{L}{ }^{-1}\right.$ day $\left.^{-1}\right)$. Future studies should aim to improve the gas flux rate of the DM, for example, by changing membrane materials (Liang et al., 2002). The average biogas collection rates calculated by excluding the amount of air from the collected biogas (i.e., biogas flux through the DM) were $150 \pm 14 \mathrm{~mL} \mathrm{~m}^{-2}$ day $^{-1}$ in phase 1.3 and $150 \pm 24 \mathrm{~mL} \mathrm{~m}^{-2} \mathrm{day}^{-1}$ in phase 6.2 (Figure 3B), indicating that the decrease in biogas flux due to membrane fouling was negligible in this study.

\section{Conclusions}

In this study, the bench scale UASB reactor equipped with the DM reactor was operated at different temperatures and HRTs for 170 days. D- $\mathrm{CH}_{4}$ was successfully collected by degasification with the DM. Under lower temperatures or shorter HRTs, 
the D-CH 4 concentrations increased; therefore, the $\mathrm{D}-\mathrm{CH}_{4}$ collection efficiencies increased. Moreover, the P-COD concentration was decreased by degasification. These results indicated that degasification is a promising technology for improving $\mathrm{CH}_{4}$ recovery and $\mathrm{P}-\mathrm{COD}$ removal efficiencies of the UASB process for treating low-strength wastewater at low temperature.

\section{Acknowledgements}

This work was partially supported by the funding for Basic and Applied Researches on Construction Technologies from the Ministry of Land, Infrastructure, Transport, and Tourism of Japan.

\section{References}

Angenent, L.T., Banik, G.C., Sung, S.W. (2001) Anaerobic migrating blanket reactor treatment of low-strength wastewater at low temperatures. Water Environment Research 73(5), 567-574.

Bandara, W.M.K.R.T.W., Ikeda, M., Satoh, H., Sasakawa, M., Nakahara, Y., Takahashi, M., Okabe, S. (Submitted) Recovery of dissolved methane gas discharged from a UASB reactor with a degassing membrane. Water Science and Technology.

Cakir, F.Y., Stenstrom, M.K. (2005) Greenhouse gas production: A comparison between 
aerobic and anaerobic wastewater treatment technology. Water Research 39(17), 4197-4203.

Dhaked, R.K., Singh, P., Singh, L. (2010) Biomethanation under psychrophilic conditions. Waste Management 30(12), 2490-2496.

Elmitwalli, T.A., van Lier, J., Zeeman, G., Lettinga, G. (2003) Treatment of domestic sewage at low temperature in a two-anaerobic step system followed by a trickling filter. Water Science and Technology 48(11-12), 199-206.

Fang, H.H.P., Liang, D.W., Zhang, T., Liu, Y. (2006) Anaerobic treatment of phenol in wastewater under thermophilic condition. Water Research 40(3), 427-434.

Gomec, C.Y., Letsiou, I., Ozturk, I., Eroglu, Y., Wilderer, P.A. (2008) Identification of archaeal population in the granular sludge of an UASB reactor treating sewage at low temperatures. Journal of Environmental Science and Health, Part A 43(13), 1504-1510.

Hartley, K., Lant, P. (2006) Eliminating non-renewable $\mathrm{CO}_{2}$ emissions from sewage treatment: An anaerobic migrating bed reactor pilot plant study. Biotechnology and Bioengineering 95(3), 384-398.

Hatamoto, M., Yamamoto, H., Kindaichi, T., Ozaki, N., Ohashi, A. (2010) Biological 
oxidation of dissolved methane in effluents from anaerobic reactors using a down-flow hanging sponge reactor. Water Research 44(5), 1409-1418.

Kashyap, D.R., Dadhich, K.S., Sharma, S.K. (2003) Biomethanation under psychrophilic conditions: a review. Bioresource Technology 87(2), 147-153.

Lettinga, G., Rebac, S., Zeeman, G. (2001) Challenge of psychrophilic anaerobic wastewater treatment. Trends in Biotechnology 19(9), 363-370.

Lettinga, G., Rebac, S., Parshina, S., Nozhevnikova, A.N., van Lier, J.B., Stams, A.J. (1999) High-rate anaerobic treatment of wastewater at low temperatures. Applied and Environmental Microbiology 65(4), 1696-1702.

Liang, T.M., Cheng, S.S., Wu, K.L. (2002) Behavioral study on hydrogen fermentation reactor installed with silicone rubber membrane. International Journal of Hydrogen Energy 27(11-12), 1157-1165.

Luostarinen, S.A., Rintala, J.A. (2005) Anaerobic on-site treatment of black water and dairy parlour wastewater in UASB-septic tanks at low temperatures. Water Research $39(2-3), 436-448$

Madden, P., Chinalia, F.A., Enright, A.M., Collins, G., O’Flaherty, V. (2010) 
Perturbation-independent community development in low-temperature anaerobic biological wastewater treatment bioreactors. Biotechnology and Bioengineering 105(1), $79-87$.

Matsushige, K., Inamori, Y., Mizuochi, M., Hosomi, M., Sudo, R. (1990) The effects of temperature on anaerobic filter treatment for low-strength organic wastewater. Environmental Technology 11(10), 899-910.

Matsuura, N., Hatamoto, M., Sumino, H., Syutsubo, K., Yamaguchi, T., Ohashi, A. (2010) Closed DHS system to prevent dissolved methane emissions as greenhouse gas in anaerobic wastewater treatment by its recovery and biological oxidation. Water Science and Technology 61(9), 2407-2415.

McKeown, R.M., Scully, C., Mahony, T., Collins, G., O’Flaherty, V. (2009) Long-term (1243 days), low-temperature $\left(4-15^{\circ} \mathrm{C}\right)$, anaerobic biotreatment of acidified wastewaters: Bioprocess performance and physiological characteristics. Water Research 43(6), 1611-1620.

Pauss, A., Andre, G., Perrier, M., Guiot, S.R. (1990) Liquid-to-gas mass transfer in anaerobic processes: Inevitable transfer limitations of methane and hydrogen in the biomethanation process. Applied and Environmental Microbiology 56(6), 1636-1644. 
Satoh, H., Miura, Y., Tsushima, I., Okabe, S. (2007) Layered structure of bacterial and archaeal communities and their in situ activities in anaerobic granules. Applied and Environmental Microbiology 73(22), 7300-7307.

Trzcinski, A.P., Stuckey, D.C. (2010) Treatment of municipal solid waste leachate using a submerged anaerobic membrane bioreactor at mesophilic and psychrophilic temperatures: Analysis of recalcitrants in the permeate using GC-MS. Water Research 44(3), 671-680.

Voolapalli, R.K., Stuckey, D.C. (1998) Stability enhancement of anaerobic digestion through membrane gas extraction under organic shock loads. Journal of Chemical Technology and Biotechnology 73(2), 153-161.

Xing, W., Zuo, J.E., Dai, N., Cheng, J., Li, J. (2009) Reactor performance and microbial community of an EGSB reactor operated at 20 and $15^{\circ} \mathrm{C}$. Journal of Applied Microbiology 107(3), 848-857. 


\section{Figure Captions}

Figure 1. Concentrations of influent total chemical oxygen demand (T-COD) and effluent T-COD and dissolved fraction of COD (D-COD) in the upflow anaerobic sludge blanket (UASB) reactor, and D-COD removal efficiency of the UASB reactor. The gray area represents a degasification period. Operational conditions in each phase are summarized in Table 1.

Figure 2. Dissolved methane $\left(\mathrm{D}-\mathrm{CH}_{4}\right)$ concentrations in the upflow anaerobic sludge blanket (UASB) and degassing membrane (DM) reactors, and $\mathrm{D}-\mathrm{CH}_{4}$ collection efficiency of the DM reactor. The gray area represents a degasification period. Operational conditions in each phase are summarized in Table 1.

Figure 3. Gas compositions in the headspace of the upflow anaerobic sludge blanket (UASB) reactor (A) and inside the lumen of the hollow fibers of the degassing membrane (DM), and gas flux into the hollow fibers of the DM (B). The gray area represents a degasification period. Operational conditions in each phase are summarized in Table 1.

Figure 4. Rates (mg COD L ${ }^{-1}$ day $^{-1}$ ) of $\mathrm{CH}_{4}$ evolution in the upflow anaerobic sludge blanket (UASB) headspace, $\mathrm{CH}_{4}$ collection from the degassing membrane (DM), and $\mathrm{CH}_{4}$ discharge from the UASB and DM reactors, as well as total $\mathrm{CH}_{4}$ recovery efficiency. The gray area represents a degasification period. Operational conditions in 
each phase are summarized in Table 1. 
TABLE 1. Summary of operational conditions and reactor performances in the UASB and DM reactors

\begin{tabular}{|c|c|c|c|c|c|c|}
\hline Phase & $\begin{array}{l}\text { Influent T-COD } \\
\text { concentration } \\
(\mathrm{mg} / \mathrm{L})\end{array}$ & $\begin{array}{c}\text { T-COD } \\
\text { loading rate } \\
\text { (mg/L/h) }\end{array}$ & $\begin{array}{l}\text { HRT of UASB } \\
\text { (hour) }\end{array}$ & $\begin{array}{l}\text { HRT of DM } \\
\text { (hour) }\end{array}$ & $\begin{array}{c}\text { Temperature } \\
\left({ }^{\circ} \mathrm{C}\right)\end{array}$ & $\begin{array}{l}\text { Transmembrane } \\
\text { pressure } \\
(\mathrm{kPa})\end{array}$ \\
\hline 1.1 & $1650 \pm 132$ & $150 \pm 10$ & $10.9 \pm 0.3$ & $9.2 \pm 0.2$ & 35 & 0 \\
\hline 1.2 & $1580 \pm 95$ & $150 \pm 4$ & $10.3 \pm 0.4$ & $8.7 \pm 0.3$ & 35 & 50 \\
\hline 1.3 & $1620 \pm 48$ & $160 \pm 10$ & $10.0 \pm 0.3$ & $8.5 \pm 0.3$ & 35 & 80 \\
\hline 1.4 & 1640 & 160 & 10.4 & 8.8 & 35 & 0 \\
\hline 2.1 & $1530 \pm 21$ & $150 \pm 7$ & $10.2 \pm 0.4$ & $8.6 \pm 0.4$ & 25 & 0 \\
\hline 2.2 & $1410 \pm 13$ & $140 \pm 5$ & $10.1 \pm 0.3$ & $8.5 \pm 0.3$ & 25 & 80 \\
\hline 2.3 & 1390 & 140 & 10.2 & 8.6 & 25 & 0 \\
\hline 3.1 & $1390 \pm 0$ & $130 \pm 7$ & $10.3 \pm 0.6$ & $8.7 \pm 0.5$ & 15 & 0 \\
\hline 3.2 & $1340 \pm 18$ & $130 \pm 4$ & $10.1 \pm 0.2$ & $8.5 \pm 0.2$ & 15 & 80 \\
\hline 3.3 & 1400 & 140 & 10.0 & 8.5 & 15 & 0 \\
\hline 4 & $1460 \pm 37$ & $150 \pm 4$ & $10.0 \pm 0.1$ & $8.4 \pm 0$ & 35 & 0 \\
\hline 5.1 & $810 \pm 30$ & $110 \pm 23$ & $5.5 \pm 1.0$ & $4.7 \pm 0.8$ & 35 & 0 \\
\hline 5.2 & $880 \pm 55$ & $89 \pm 5$ & $6.6 \pm 0$ & $5.6 \pm 0$ & 35 & 80 \\
\hline 5.3 & $950 \pm 4$ & $96 \pm 1$ & $6.6 \pm 0$ & $5.6 \pm 0$ & 35 & 0 \\
\hline 6.1 & $450 \pm 48$ & $45 \pm 5$ & $3.3 \pm 0$ & $2.8 \pm 0$ & 35 & 0 \\
\hline 6.2 & $480 \pm 5$ & $48 \pm 1$ & $3.3 \pm 0$ & $2.8 \pm 0$ & 35 & 80 \\
\hline 6.3 & 500 & 50 & 3.3 & 2.8 & 35 & 0 \\
\hline 7 & $1510 \pm 46$ & $150 \pm 5$ & $9.9 \pm 0.1$ & $8.4 \pm 0$ & 35 & 0 \\
\hline
\end{tabular}


TABLE 1-Continued

\begin{tabular}{|c|c|c|c|c|c|c|c|c|}
\hline Phase & $\begin{array}{l}\mathrm{CH}_{4} \text { evolution rate } \\
\text { (mg-COD/L/day) }\end{array}$ & $\begin{array}{l}\mathrm{CH}_{4} \text { collection rate } \\
\text { (mg-COD/L/day) }\end{array}$ & $\begin{array}{c}\mathrm{CH}_{4} \text { discharge rate } \\
\text { from UASB } \\
\text { (mg-COD/L/day) }\end{array}$ & $\begin{array}{c}\mathrm{CH}_{4} \text { discharge rate } \\
\text { from DM } \\
\text { (mg-COD/L/day) }\end{array}$ & $\begin{array}{c}\text { Total } \mathrm{CH}_{4} \\
\text { production rate } \\
\text { (mg-COD/L/day) }\end{array}$ & $\begin{array}{l}\mathrm{CH}_{4} \text { recovery rate } \\
\text { (mg-COD/L/day) }\end{array}$ & $\begin{array}{c}\text { D-CH } \mathrm{CH}_{4} \text { collectio } \\
\text { efficiency } \\
(-)\end{array}$ & $\begin{array}{c}\text { Total } \mathrm{CH}_{4} \text { recovery } \\
\text { efficiency } \\
(-)\end{array}$ \\
\hline 1.1 & $960 \pm 220$ & & $140 \pm 14$ & & $1090 \pm 230$ & $960 \pm 220$ & & $89 \pm 3$ \\
\hline 1.2 & $1000 \pm 94$ & $180 \pm 85$ & $150 \pm 7$ & $49 \pm 10$ & $1220 \pm 140$ & $1180 \pm 150$ & $68 \pm 7$ & $96 \pm 1$ \\
\hline 1.3 & $1120 \pm 110$ & $210 \pm 26$ & $150 \pm 4$ & $35 \pm 11$ & $1370 \pm 130$ & $1340 \pm 130$ & $77 \pm 7$ & $97 \pm 1$ \\
\hline 1.4 & $1010 \pm 230$ & & $150 \pm 3$ & & $1160 \quad 230$ & $1010 \pm 230$ & & $90 \pm 2$ \\
\hline 2.1 & $880 \pm 91$ & & $190 \pm 16$ & - . - - - & $1080 \pm 85$ & $880 \pm 91$ & & $85 \pm 2$ \\
\hline 2.2 & $930 \pm 69$ & $300 \pm 84$ & $210 \pm 27$ & $32 \pm 11$ & $1260 \pm 59$ & $1230 \pm 54$ & $85 \pm 4$ & $97 \pm 1$ \\
\hline 2.3 & $580 \pm 93$ & & $190 \pm 3$ & & $770 \pm 97$ & $580 \pm 93$ & & $78 \pm 1$ \\
\hline 3.1 & $530 \pm 25$ & & $240 \pm 19$ & & $780 \pm 37$ & $530 \pm 25$ & & $71 \pm 2$ \\
\hline 3.2 & $700 \pm 73$ & $370 \pm 100$ & $240 \pm 7$ & $33 \pm 4$ & $1100 \pm 150$ & $1060 \pm 150$ & $86 \pm 2$ & $97 \pm 1$ \\
\hline 3.3 & 720 & & $250 \pm 20$ & & $610 \pm 490$ & 720 & & 76 \\
\hline 4 & $1390 \pm 160$ & & $160 \pm 12$ & & $1550 \pm 170$ & $1390 \pm 160$ & & $90 \pm 1$ \\
\hline 5.1 & $1220 \pm 100$ & & $240 \pm 14$ & & $1460 \pm 110$ & $1220 \pm 100$ & & $84 \pm 1$ \\
\hline 5.2 & $1350 \pm 47$ & $480 \pm 130$ & $250 \pm 19$ & $45 \pm 4$ & $1870 \pm 160$ & $1830 \pm 160$ & $82 \pm 1$ & $98 \pm 0$ \\
\hline 5.3 & $1150 \pm 190$ & & $240 \pm 14$ & & $1390 \pm 190$ & $1150 \pm 190$ & & $84 \pm 2$ \\
\hline 6.1 & $830 \pm 63$ & & $480 \pm 35$ & & $1320 \pm 95$ & $830 \pm 63$ & & $64 \pm 1$ \\
\hline 6.2 & $770 \pm 33$ & $370 \pm 12$ & $500 \pm 41$ & $370 \pm 25$ & $1500 \pm 16$ & $1140 \pm 31$ & $26 \pm 7$ & $76 \pm 2$ \\
\hline 6.3 & $960 \pm 280$ & & $510 \pm 19$ & & $1480 \pm 300$ & $960 \pm 280$ & & $69 \pm 5$ \\
\hline 7 & $810 \pm 540$ & & $150 \pm 125$ & & $1220 \pm 600$ & $1300 \pm 76$ & & $90 \pm 1$ \\
\hline
\end{tabular}


TABLE 2. Characteristics of the degassing membrane module

\begin{tabular}{lc}
\hline Item & Characteristics \\
\hline $\begin{array}{l}\text { Non-porous layer } \\
\text { for degassing }\end{array}$ & Polyethylene \\
$\begin{array}{l}\text { Porous layer } \\
\text { Outer diameter } \\
\text { of a hollow fiber }\end{array}$ & Polyurethane \\
Inner diameter & $280 \mu \mathrm{m}$ \\
of a hollow fiber & $200 \mu \mathrm{m}$ \\
Thickness & \\
Length & $40 \mu \mathrm{m}$ \\
Number of hollow fiber & $360 \mathrm{~mm}$ \\
Total membrane area & 5500 \\
Membrane volume & $1.7 \mathrm{~m}^{2}$ \\
\hline
\end{tabular}




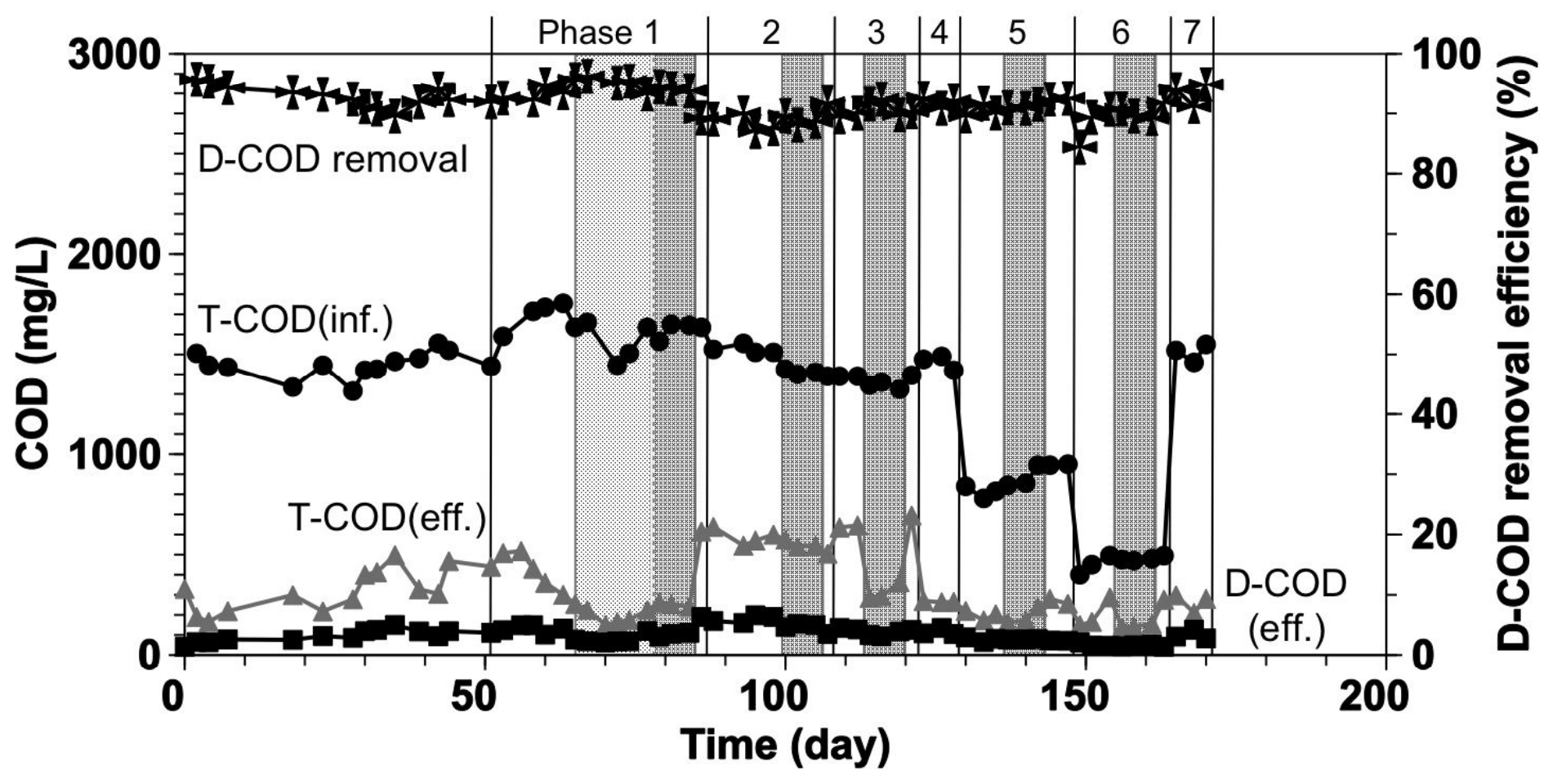

Figure 1

Wasala et al. 


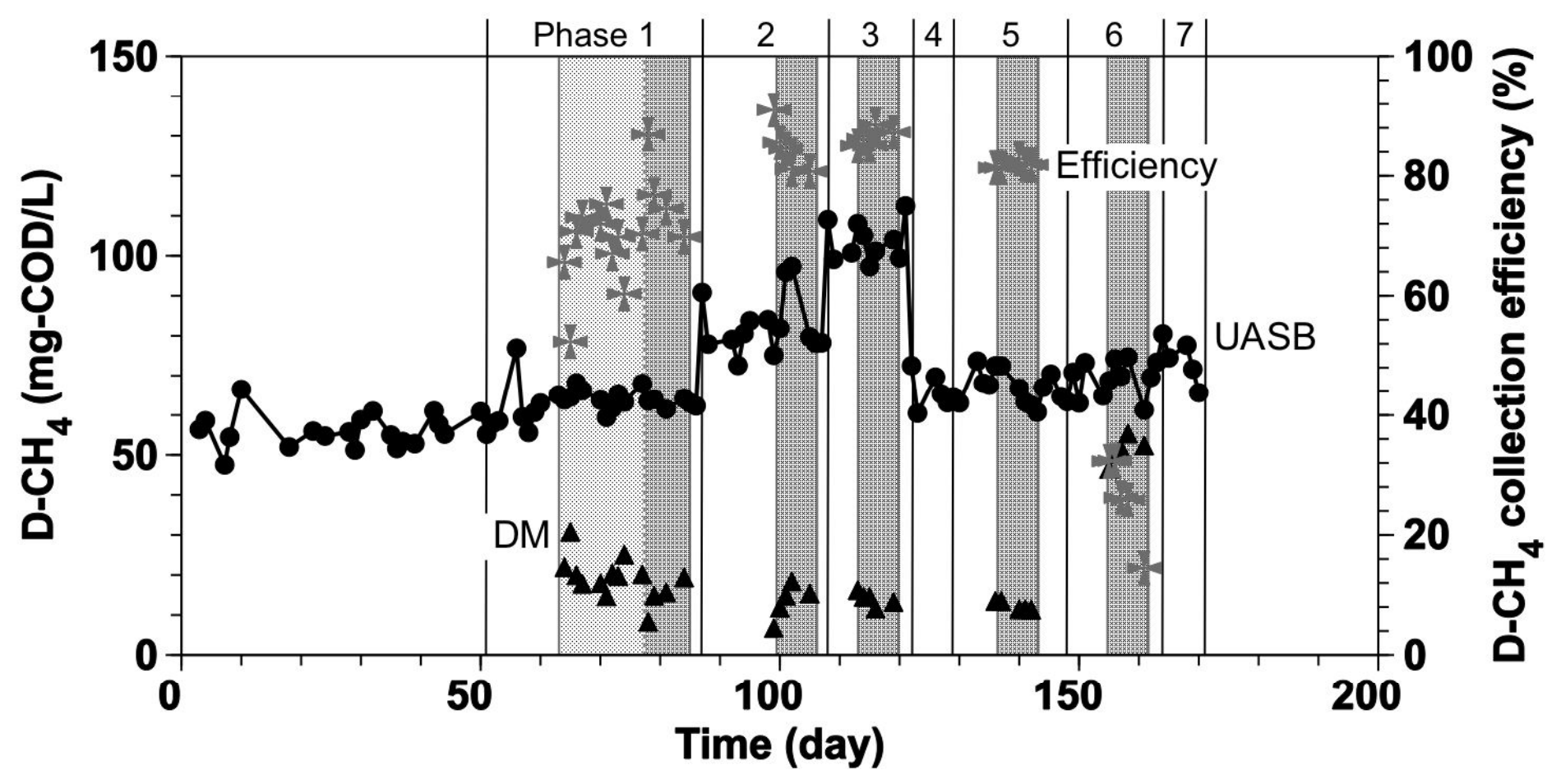

Figure 2

Wasala et al. 

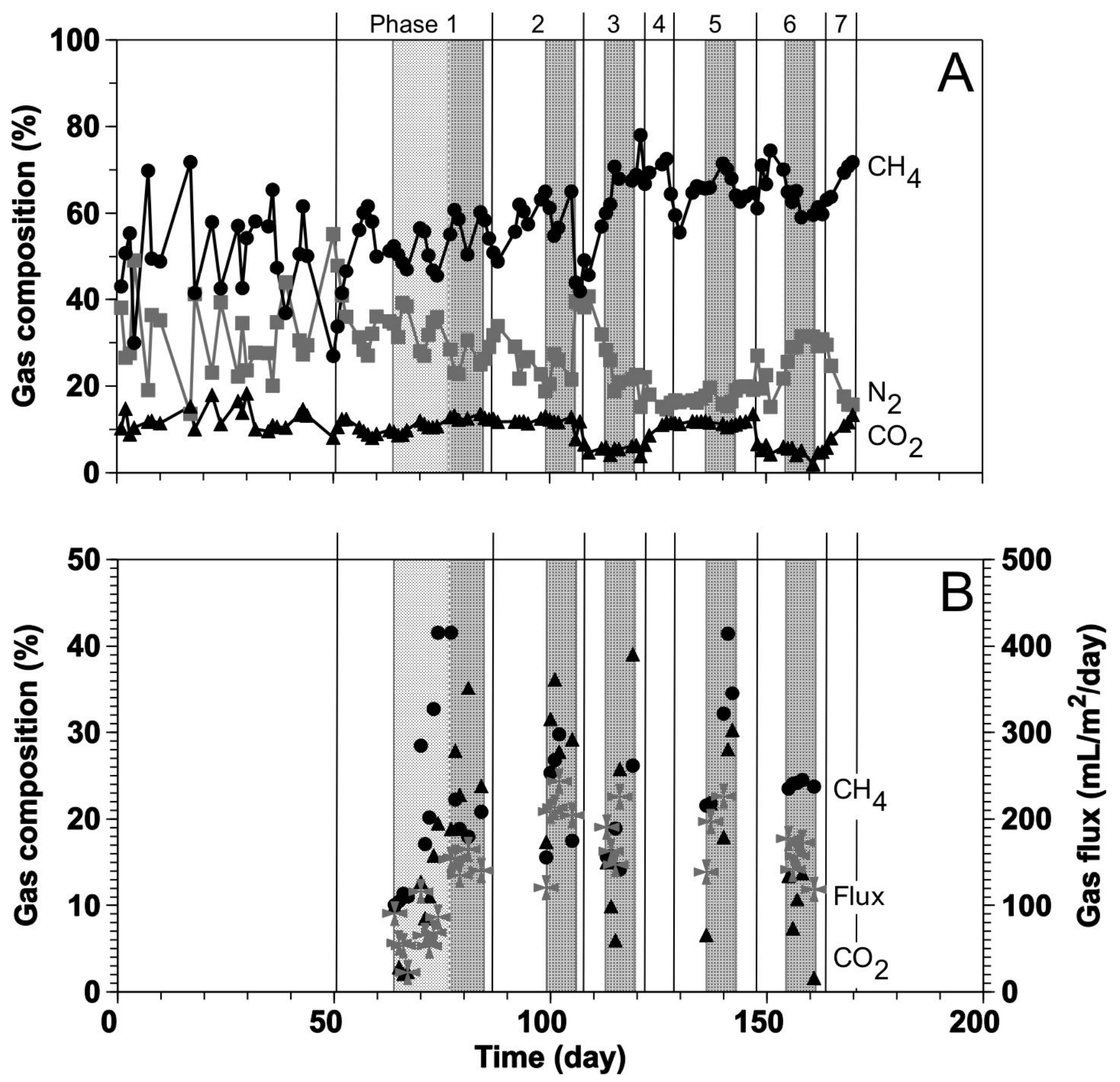

Figure 3

Wasala et al. 


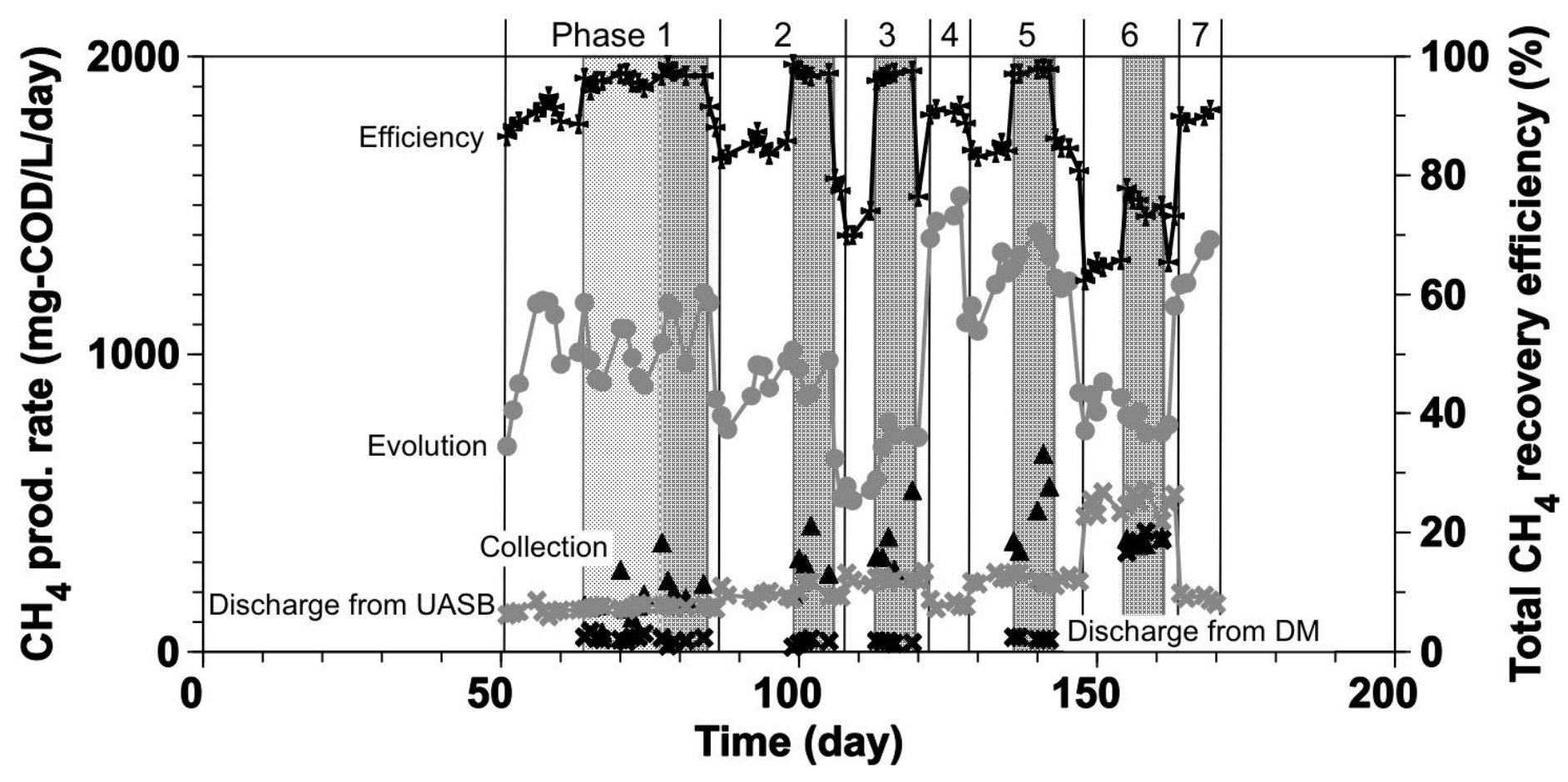

Figure 4 Wasala et al. 